\title{
TSpace
}

The University of Toronto's research repository

\section{Accepted Manuscript of Masyarakat adat, difference, and the limits of recognition in Indonesia's forest zone}

\section{How to cite TSpace items}

Always cite the published version, so the author(s) will receive recognition through services that track citation counts, e.g. Scopus. If you need to cite the page number of the TSpace version ${ }^{1}$ because you cannot access the published version ${ }^{2}$, then cite the Tspace version in addition to the published version.

Published version citation:

Li, Tania M.

2001 Masyarakat adat, difference, and the limits of recognition in Indonesia's forest zone. Modern Asian Studies 35(3): 645-676.

TSpace version citation:

Li, Tania M.

2001 Masyarakat adat, difference, and the limits of recognition in Indonesia's forest zone. TSpace. Available at http://hdl.handle.net/XXXX/XXXXX. Replace the 'XXXX/ XXXXX' with the item handle from the URL, i.e. the last 9 digits.

\section{tspace.library.utoronto.ca}

\footnotetext{
${ }_{1}^{1}$ TSpace version: includes the pre-print/original manuscript (version before peer review) and post-print/ accepted manuscript (version after peer-review and editing).

2 Published version: the publisher's final PDF.
} 


\section{Masyarakat Adat, Difference, and the Limits of Recognition in Indonesia's Forest Zone}

\section{Tania M. Li}

"We will not recognize the Nation, if the Nation does not recognize us"

This statement was made by AMAN (Aliansi Masyarakat Adat Nusantara), the Alliance of Indigenous People of the Archipelago, at their inaugural congress in Jakarta, March 1999. The congress was organized by a consortium of Jakarta based NGOs, and funded by international donors (USAID, CUSO, and OXFAM among others). Building upon a process of mobilization that began with the International Year of Indigenous People in 1993, the Congress marked the formal entry of masyarkat adat (literally, people who adhere to customary ways) as one of several groups staking claims and seeking to redefine its place in the Indonesian nation as the political scene opened up after Suharto's long and repressive rule. AMAN and its supporters assert cultural distinctiveness as the grounds for securing rights to territories and resources threatened by forestry, plantation and mining interests backed by police and military intimidation. Their attempt to place the problems of masyarakat adat on the political agenda has been remarkably successful. While seven years ago the head of the national land agency declared that the category masyarakat adat, which had some significance in colonial law, was defunct or withering away (Kisbandono I8/02/93), the term now appears ever more frequently in the discourse of activists, parliamentarians, media, and government officials dealing with forest and land issues.

The official view in Indonesia, at least until recently, was that the international legal category "indigenous people" did not fit Indonesia's situation: either all the people native to the archipelago are indigenous, or no one is (Kusumatmadja 1993). ${ }^{\mathrm{I}}$ There is no colonial or post-colonial history of reserving land for particular ethnic or cultural groups, and such distinctions are not recorded in the census or used to differentiate citizens for the purpose of rule. Nor is race the usual idiom for understanding the differences between groups native to the archipelago. Folk concepts of difference focus rather on language and cultural practice, understood as mutable formations concentrated in particular ethnic groups (suku) but not inherent in them. ${ }^{2}$ Nor is 
difference - whether cultural or ethnic - the primary liability of the people now demanding recognition as masyarkat adat. Although the numerically dominant Javanese are sometimes accused of ethnocentrism in their attitudes towards residents of the other islands (Dove I985), all of Indonesia's rural villagers, regardless of physiognomy or cultural affiliation, were bullied in one way or another by the Suharto regime. Their resource struggles are not, for the most part, horizontal ones that pit one cultural or ethnic group against another, although these can occur. ${ }^{3}$ More centrally, it is the state apparatus, the military and capitalists in varying combinations that form the constitutive outside, the "other" in relation to which the term masyarakat adat takes on its meaning and force. As one of the delegates to AMAN's congress stated, everyone "came with their own grievances about companies in their particular areas." (Down to Earth Special Issue October 1999, hereafter DTE-SI:I3). But there are other languages in which claims against the state could be made, the rights of citizenship being the most obvious. Why then do struggles over land and resources focus on difference?

To situate this question I need to explain the concerns, at once personal and political, which drive my inquiry. First there is a sense of puzzlement shared, I think, among many observers of the Indonesian scene, unclear about who exactly is encompassed by the term masyarakat adat. AMAN defines indigenous people as "communities which have ancestral lands in certain geographic locations and their own value systems, ideologies, economies, politics, cultures and societies in their respective homelands"(DTE-SI:4). But most Indonesians lay claim to a distinctive cultural heritage rooted in a particular region. While AMAN's focus is on people still residing on their ancestral land, it is not clear that the definition excludes the intellectuals and aristocrats who identify themselves as masyarakat adat but happen to live in cities, or people such as the Dayak who have been migrating out from the interior of Kalimantan towards the coast for the past century. ${ }^{4}$ Neither does AMAN invoke the familiar contrast between intensively farmed, industrialized and urbanized Java and the "outer islands" with their more extensive farming systems, lower population densities, and still-forested interiors. AMAN's elected assembly is to include fifty-four representatives, a man and a woman from each province including the four provinces of Java, with extras for West Papua due to its size. Nor, significantly, do AMAN's statements emphasize or limit masyarakat adat to a place in nature or a subsistence niche, although a general environmental conscience is implied (AMAN statements and SK No.I/1999, cited in DTE-SI:4). AMAN considers masyarakat adat to number "tens of millions" (AMAN IO/09/99; 25/05/99) suggesting a definition of much broader scope than the government category of "isolated communities," one million overall (Social Affairs I994/95). Consistent with ILO I69's stress on self identification as the key to indigeneity, AMAN does not seem concerned to draw a tight boundary: as more people see their struggles 
reflected in the concept of masyarakat adat, so the number will grow. But is this the scenario that the various parties now using the term so frequently and in apparently unproblematic ways have in mind?

My second concern is the danger I associate with a politics of difference in general, and the racialization of territory in particular. The essence of AMAN's demand is that the state acknowledge masyarakat adat as so many (thousand) sovereign communities with the right to govern themselves and the resources on which they depend. The basis for this claim is that they existed as organized collectivities with sovereign powers over their lives and living space "long before the nation state". To make this argument AMAN projects culturally distinctive, bounded, self-governing communities as Indonesia's aboriginal social form. It truncates history to occlude the colonial period, presenting adat as "the way resources were locally managed prior to the rise of foreign investment and forest industry in the 1960s" (Peluso 1995:399). Thus the (assumed) autonomous social forms of the past, which are now to be reasserted, are not too far out of reach. AMAN's objection is to the way the New Order regime has unilaterally abrogated those rights, reallocated their resources, and dismantled their customary institutions and practices through various legal instruments, notoriously the Basic Forest Law of 1967 and the Village Government Law of 1979. AMAN thus reclaims the right to ways of life linked to the specific ancestral territories of distinctive cultural groups. But what about the people who find themselves out of place? How would territorial links be assessed in view of the centuries of migration that have occurred within and between the various islands of the archipelago, voluntarily or under duress? Images of mini-republics and ethnic cleansing come too readily to mind. Even if violent exclusions could be avoided, is there not a danger that defense of place would yield to a kind of social incarceration? This concern stems from my fieldwork among people who live in a remote corner of Sulawesi, but who have long been involved in commerce, admire urban consumer styles and desire to emulate them, and are busy commoditizing their ancestral land to that end (Li I996; Li I997; Li 200I). Their struggles, which center on transforming nature in order to claim a place in the modern world, have given me a general suspicion of platforms which would limit or consign them to ancestral territories and ways of life. For all the failure of the Indonesian state to deliver the promises of liberal citizenship, I worry too about a differentiated legal system in which recognition of customary law would subject people to local despotisms and the whims of "traditional" leaders who could monopolize or sell collective resources, or pass unreasonable judgements, substituting one tyranny for another (Cooper 1994:I544).

Finally, I have the predictable, left-leaning concern that the politics of difference might be a distraction or mask for a struggle that is, or should be, about class-based 
inequalities and democracy. 5 I understand that a politics of difference may be unavoidable in nations where racial and cultural divisions are deeply inscribed both as the liabilities that must be contested and the framework within which mobilization most readily occurs. However, Indonesia has a history of popular struggles that were phrased in the early days of independence under Sukarno, and later under the influence of the Indonesian communist party, not as the claims of distinctive, culturebound communities (masyarakat adat), but as struggles of "the people" (rakyat). Is the shift of focus from people to culture, which coincides with a shift of the site of struggle from agricultural land to forests and nature, the best approach to justice?

These concerns are still with me, but closer examination of the politics of difference being conducted by and on behalf of Indonesia's masyarakat adat has started to alleviate them. From all I have read and observed, nothing about the movement is exclusive or chauvinistic. Indeed, as I suspected, it is so inclusive that no coherent boundaries can be drawn, but that is not the point. Rather, diverse parties are being drawn into a struggle for an imagined future which is inspired by the past, but takes its shape from the injustices that need to be confronted in the present. Besides those who might claim the identity masyarakat adat as their own, the people caught up in this movement include government officials and parliamentarians, donors and activists, academics and the media. As populist sentiments silenced by Suharto are reawakened, I suspect that there is broad support for the idea that people who live in "customary ways" should be allowed to continue to do so without having their resources stolen from them by greedy elites. AMAN's demands, far from being narrow or sectarian, continually blur the boundaries between rakyat and masyarakat adat to pose a fundamental challenge to what the state has become, and argue for a comprehensive re-evaluation of the meaning of citizenship. The goal at this point is to form alliances with other groups including those described as farmers or as other "local people," stressing common causes rather than dwelling on the details (about identities and resource entitlements) which could - but may not - divide them.

The category masyarakat adat and the social movement assembled around it has particular roots. It is not simply a replay of Amazonian eco-naturalism, nor a continuation of the drama in which the Penan of Malaysia confronted bulldozers, although elements of these struggles are relevant here. Nor are the questions it raises exhausted by the issue of essentialism, its deconstruction or tactical deployment. It is true that images of exotic tribes in tune with nature figure in AMAN's repertoire, as does a rather idealized "collective wish image" (Watts 1999:88) of the past to be made future. But this is not surprising since I assume that "a touch of essentialism"(Hall 1996c:472) is always needed to draw the boundaries which enable political mobilization. More significantly, my exploration of the fields of force within and against which this 
politics has emerged suggests the inadequacy of analytical models centered on sovereign subjects enacting strategies of their own choosing. The category masyarakat adat has not been conceptualized, constructed, selected, occupied, fought for or manipulated as one option among others: the structures of recognition and identification in which it is embedded are much too broad and deep to sustain this kind of explanation. ${ }^{6}$ Shorn of voluntarism, my concern over whether a politics of difference is "the best approach," also needs to be rethought. The analytical intervention that seems worthwhile, at this conjuncture, is the attempt to understand why politics is taking this form - its genealogy, and its limits, as far as these can be discerned. More specifically I ask: What are the fields of force, at once material and discursive, within and against which the category masyarakat adat has emerged and taken on political weight? Through what processes are demands for recognition made by or on behalf of masyarakat adat limited or contained?

\section{Hegemony and the Limits of Recognition}

The category masyarakat adat, the community it imagines, the problems which bind people and the ways they are addressed are configured by existing fields of force (Roseberry I996:80-8I). This is the "contradictory complexity" of subaltern politics fully embraced by Gramsci in his account of hegemony but underestimated by those who imagine new social movements to operate in autonomous spaces outside of power. ${ }^{7}$ Because subaltern subjectivities are formed within hegemonic relations, the process of ideological struggle seldom involves a "whole new alternative set of terms" but proceeds rather through the attempt to "win some new set of meanings for an existing term or category ... dis-articulating it from its place in the signifying structure," and "rearticulating its associations" with other ideas and with particular social forces (Hall 1985:II2; Hall 1996a:434). Hegemonic articulations secure at most the fragile and contingent coordination of "the interests of a dominant group with the general interests of other groups and the life of the state as a whole" (Gramsci cited inHall 1996a:423).

In Indonesia as in other modern state systems, a "new terrain of politics [has been] created by the emerging forms of state and civil society, and new, more complex relations between them" (Hall I996a:427). As the boundaries between state and civil society become increasingly blurred, struggles must be "conducted in a protracted way, across many different and varying fronts" (Hall 1996a:426). The fields of force surrounding Indonesia's masyarakat adat are not concentrated in a singular class enemy or in the state apparatus but distributed across various institutional sites. To take just one example, while the kind of power Foucault (I99I) described as governmental, that which is concerned with regulating the "conduct of conduct" is concentrated in the apparatus we have come to call "the state," it is also a feature of 
many of the organizations we have come to call "non-governmental". "N"-GOs and activists working on environment and development are often concerned with how people live their lives, and are exercising governmental power when they seek to reform them in an "improving direction." 8 Even NGOs dedicated to the restoration of the integrity of indigenous cultures and the preservation of traditional environmental knowledge imagine an ideal state (sometimes projected as a prior state) to which people should conform. Governmentality, as Foucault acknowledged, is always guided by a moral vision, and competing moral projects are central to the struggle for hegemony, especially for dominance in the configuration of what will count as everyday, popular, common sense (Hall I996a:43I-2).

The fields of power surrounding recognition, AMAN's key demand, are especially complex. To open these up for scrutiny, it is useful to dwell for a moment on the word recognition itself, which in English elides a number of meanings. Detouring through the German language, Johannes Fabian (I999:53) identifies three: Erkennen, meaning "I know these persons or objects when I see them" (an act of cognition); Wiedererkennen, "I know these persons or objects because I remember them" (an act of memory); and Anerkennen "I give these persons or objects the recognition they ask for and deserve" (an act of acknowledgement). Note that recognition in the first sense is about classification: an object or person is knowable because it meets the criteria of a pre-established cognitive slot, which could be an everyday "map of meaning" or a legal-bureaucratic category. Recognition as memory has an imaginative and emotional component, which draws variously upon experience, projection and déjà vu. The element of desire distinguishes it, sometimes only slightly, from recognition as classification. Recognition as acknowledgement has been, as Fabian points out, the focus of debates in political philosophy concerned with theories of the good life and the attempt to reconcile the interests of individuals and collectivities (Fabian 1999:64; Taylor 1994). For Fabian recognition as acknowledgement is not something that can simply be granted by one party to another. It cannot be "doled out like political independence or development aid"(I999:66), or it is merely "ethnocentric righteousness in the guise of supposedly universal principles"(1999:65). Acknowledgement requires knowledge, and knowledge cannot be "brought along", as memory, projection or classificatory schemes. It is the product of confrontation and struggle, of communicative exchanges between "coeval participants", with all their potentially upsetting consequences, including the unsettling of identities (1999:66). Knowledge changes people. Ideally, it is reciprocal.

AMAN's demand for recognition invokes each of these dimensions. The idea that masyarakat adat have special rights, or that resource access should be linked to cultural identity and "traditional" environmental knowledge, would mean nothing if the bearers of those rights and qualities could not be identified and rendered recognizable 
by legal and bureaucratic criteria. Supporters too need to be able to identify the subjects of their concern. If identification is power-laden so too is the way memory works to apprehend the present through an imagined or projected past. Recognition as memory depends upon a repetition of what has been encountered before, if only as image or myth. To be recognized in this sense, masyarakat adat must fit into and build upon images that are already available. The space they may fill is configured by national and transnational desires to retrieve a past of cooperative and autonomous village communities, subsistence security, abundant natural resources and spiritual attachments to the land. Alternative memories of the past as a harsh and difficult struggle to overcome nature, attain a civilized state, and attract the attention of rulers bearing secular or spiritual powers - or development funds - are filtered out of this scenario. Finally, acknowledgement. AMAN makes the claim that masyarakat adat are sovereign groups which existed prior to the nation and whose legal systems are coequal with national laws, not subsumed within or subordinate to them. But there is a paradox here. Why should masyarakat adat demand recognition from a state whose jurisdiction over them is being challenged? The organization of AMAN by provinces, its adoption of notations which repeat those of the government (statutes, letters of clarification) and the demand for recognition itself acknowledge the legitimacy of the nation even as they challenge it. Notably, the group unwilling to compromise during the Congress were the West Papuans: they refused to join the team drafting AMAN's political agenda on the grounds that their goal is not recognition but independence (DTE-SI: IO). Implicitly, AMAN concedes to the power relations that frame and limit its most radical demand. Moreover the assertion of a co-equal - and co-eval - presence is undermined by the very association of masyarakat adat with times past, making it more difficult for the surprises and shifts, the generation of new knowledge of self and other, on which acknowledgement depends.

Those who demand that their rights be acknowledged must fill the places of recognition that others provide, using dominant languages and demanding a voice in bureaucratic and other power-saturated encounters, even as they seek to stretch, reshape, or even invert the meanings implied (Roseberry 1996:8I). Despite the countervailing dialectic implied in AMAN's threat to withhold recognition from the state, exposing the fragility of relations of rule, the surrounding field of force is too complex to be undone in such a binary fashion. The "others" with whom those who seek recognition must engage include government departments with diverse agendas; colonial and contemporary legal codes, subject to interpretation; individual politicians and bureaucrats with more or less populist inclinations; international donors; national and international "non-governmental" organizations; and the media which both forms and responds to the common-sense understandings and sentiments of the "national- 
popular". By taking a lead from Roseberry (1996) and thinking of these as "fields" or concentrations of power or, as Cooper (1994:1533) puts it, arteries rather than capillaries, it is possible to investigate their characteristic configurations, as well as the ways they overlap and intersect.

\section{Fields of Power and the Genealogy of Masyarakat Adat}

\section{Capitalist Accumulation and State Agendas}

The New Order regime took power in 1965 after bloody massacres directed against alleged communists and Chinese. Popular mobilization to seize and redistribute colonial plantation land ended abruptly, and it became impossible to organize on the basis of class or the kinds of mass struggle implied by the term rakyat. The regime also declared race, ethnicity, regionalism and religion illegitimate grounds for politics, as if these would unleash uncontrollable passions and more violence, a deeply cynical move in view of the evidence that the attacks on Chinese in 1965 (and again in 1997) had been instigated by the military itself. The regime began to refer to the citizenry as masyarakat, a term which emphasizes community and socialization, as part of a deliberate attempt to quell the disruptions of "politics" and refocus rural energies on production and "development" (Langenberg 1990).

In 1967 the regime's attention shifted to Indonesia's outer islands with their extensive land and forest resources, and a forest law was passed declaring state ownership over all land not held under private title, the area amounting to seventy five percent of the nation's territory. Forests were handed over for exploitation by national and transnational capitalists, military and government officials in various combinations. The people inhabiting these forest areas, who considered themselves to have private, customary, communal or individual land rights guaranteed by the 1945 Constitution and by the 1957 Basic Agrarian Law (a product of Sukarno era populism), were ignored. If recognized at all, it was not for their cultural diversity and particular territorial attachments, but rather through the homogenized, negative and a-cultural categories "isolated community" (masyarakat terasing), shifting cultivator, or forest squatter. Their forest uses were deemed illegal, and they were subject to harassment and displacement whenever they were found to be in the way.

Although I have used the past tense, this field of force still exists and in some areas it is out of control as military and government personnel take advantage of the post Suharto vacuum to steal timber from reserved forests and national parks (Dursin 24/o2/oo; Richardson 0I/o2/oo). Moreover the monetary crisis of 1997 and IMF loan conditions have pressured the new regime to give priority to expanding exports (Anon oI/05/oo). The forests of Kalimantan - intact, logged over or burned - are slated for conversion to massive palm-oil plantations, permanently appropriating them from local use, and West Papua faces an even greater onslaught. These "developments" 
continue to be backed by brute force, arrests, beatings and harassment, although opposition by villagers, sometimes drawing upon activist support and encouraged by sympathetic media coverage, is increasingly resilient (Anon 04/03/oo). In March 2000 the press reported that fifty concessionaires holding ten million hectares throughout the country had been forced to cease their operations due to land conflicts with villagers (Anon 09/03/00). Some concessionaires have tried to buy peace by offering villagers cash compensation, while others call upon the government to confirm the legal standing of their forest contracts in the face of overlapping claims (Anon 25/03/00).

This political-economic scenario accounts in part for the form taken by the movement for masyarakat adat, and its emphasis upon difference. Masyarakat adat assert what the New Order denied: the intrinsic value of diverse cultural forms, the capacity of villagers to organize themselves and garner livelihoods from existing resources without state direction or "development", attachments to place which cannot be compensated by two hectare allocations in new settlement schemes, and a vision of nature which resists its reduction to the monotones of timber or oil-palm and highlights various, sustainable, local uses. But difference as the converse of New Order (mal)development does not explain everything. Both under Suharto and subsequently, the media seem to report ordinary villagers contesting state appropriations just as sympathetically as masyarakat adat, so difference is not essential to attract their attention. And why did it take twenty- five years of forest exploitation for the emphasis on difference to emerge? Further, if the emphasis on culture and nature associated with masyarakat adat was so challenging to the regime, why was it permitted to gather momentum even while Suharto remained in power? It is possible that the regime missed its political charge, at least initially, allowing activists to mobilize people under the cover of apparently neutral labels such as biodiversity protection. Or there may have been a calculation that exotic difference was not a serious threat - recall the "discovery" of the "stone-age" Tasaday in the Philippines under Marcos. More likely, the regime was forced to pay attention to the conservation agendas of donors and show a progressive face by passing new environmental laws, participating at Rio, and - as I will later show - agreeing that some people have such unique and special environmental knowledge that it should indeed be protected. Here one field of power impinges on another, popular struggles and donor agendas helping to shape what the state becomes.

\section{Donor Agendas, Nature Conservation and Biodiversity}

During the 1990s, nature conservation was a popular cause among donors because of its powerful international constituency and the legitimation it provided for their continuing involvement with the New Order regime. Biodiversity conservation, with its 
implied urgency (Brosius I999a:282n8), was an issue on which critics, donors, and government representatives could readily agree - at least so long as differences of interest between the various "stakeholders" were not made too explicit. Under donor sponsorship, conservation became a site for the proliferation of managerial approaches that might be seen, perhaps too cynically, as institutionalized procedures for evading difficult political questions through "increased communication and understanding". The repertoire included seminars, training, collaborative research, participatory appraisal, adaptive management, consensus building, joint fact-finding, multistakeholder meetings, enhancing organizational capacity, community mapping, shuttle diplomacy and so on. 9

What are the places of recognition allocated to masyarakat adat in conservation agendas? For some of Indonesia's transnational and national conservation organizations, human activities have no place in the "natural" environment conceived as wilderness (Cronon 1996). Many, however, subscribe to the wish-laden "middleground ... founded on the assertion that native peoples' views of nature and ways of using natural resources are consistent with Western conservationist principles" (Conklin and Graham I995:696). The compromise argument is that social groups that are unique or different should have their knowledge and rights respected if and when it is instrumental to conservation objectives. Thus only specific kinds of knowledge are relevant, and rights are conditional upon performance. The International Convention on Biological Diversity obliges states, subject to their national legislation, "to respect, preserve and maintain knowledge, innovations and practices of indigenous and local communities embodying traditional lifestyles relevant for the conservation and sustainable use of biological resources" (article 8j). It also requires them to "protect and encourage customary use of biological resources in accordance with traditional cultural practices that are compatible with conservation or sustainable use requirements" (article IOc). The niche opened up here is limited by these conditions, but for activists who assume that masyarakat adat do indeed manage their resources sustainably, there is little risked and much gained by framing arguments for masyarakat adat in terms of conservation benefits (Moniaga I993). ${ }^{\text {Io }}$

Indonesia's national strategy for implementing Agenda 2I was the outcome of extensive consultations involving government, donors, activists and academics. It illustrates the limited gains that can be made by masyarakat adat through efforts to built "consensus" under the conservation banner. The document refers strongly and repeatedly to both the knowledge and the rights of people called, variously, indigenous, traditional, local, forest dwelling and tribal. The argument moves from a recognition of indigenous knowledge and conservation-related practices to the need to "set-up a legal mechanism which protects traditional knowledge, territories, cultural practices and 
which also guarantees the genuine participation of traditional communities by recognizing their traditional laws and incorporating them into the national laws" (State Ministry for Environment and United Nations Development Program 1997:40I). Despite the rhetoric, the legal mechanisms proposed for forest-dwelling communities fall short of the recognition of their rights to occupy - still less to farm - state-forest land. The emphasis is on conservation within a forestry framework, with traditional communities as participants. The "improving direction" anticipated in the document concerns the revival and transfer of traditional wisdom, again a paradox since it is only people who have unique environmental knowledge that qualify for a place in nature to begin with.

\section{The Indigenous People's Movement and Legal Precedents}

AMAN translates masyarakat adat as indigenous people, directly linking its struggle to the international indigenous peoples' movement and claiming recognition under ILO convention I69. There is no doubt that the international movement has provided discursive and material resources for the mobilization of Indonesia's masyarakat adat, despite the lack of an obvious fit between a concept developed in the settler colonies and the Asian situation. Donor support for AMAN's inaugural congress can also be attributed to the international movement, since many donors have committed themselves to uphold the ILO convention. To meet this obligation, they need to have a "recognizable" and representative body that can be consulted when necessary, a position now filled by AMAN. But the term adat has a long and complex legal and political history in Indonesia, recalling configurations of population, territory and sovereignty which diverge significantly from internationally circulating expectations about indigenous people, especially those relating to their existence as communities prior to the colonial encounter and their place in nature.

Originally Arabic, the term adat is usually translated as custom or customary practice. It may include anything from specific rituals, to the character of everyday interactions, to the dispute resolution mechanisms imposed upon subordinate populations by pre-colonial chiefs ( $\mathrm{Li}$ 200I). Thus it has variable significance in daily affairs, but no one is entirely without adat, hence the inclusiveness of the term. In some places, adat became fixed in the colonial period when Dutch legal scholars identified nineteen distinct cultural areas and codified customary practices to provide a basis for a native legal system. The areas subjected to this kind of colonial attention, with all its reifiying, ethnicizing, and exoticizing effects, became highly invested in the idea of adat as a framework for regulating local affairs and relations with outsiders, not least the colonial power. ${ }^{\text {II }}$ The Dutch fostered mediating institutions, adat chiefs and adat councils, enhancing the position of elites in the process. ${ }^{\mathrm{I2}}$ Villagers living within an adat law area were obliged to settle disputes through the relevant adat system, but the social and territorial boundaries were never fixed by means such as maps or identity 
cards, and many areas remained outside the adat-formalization process altogether. To this day, such places lack leaders prepared to pontificate on adat, and there are no rules or institutions of the kind expected by those familiar with the Dutch volumes on adat law in the recognized, adatized places (Li 200I; Ruwiastuti 1998; Tsing 1993). Generally remote and still forested, these areas have had less access to road links, schools, churches and mosques - elements of modernity introduced or consolidated together with adat in the colonial period.

By offering a truncated version of history which moves directly from sovereign communities of the mythic past to the New Order period, skipping over centuries of colonialism, AMAN is able to include both the groups that became orderly, adat law regimes under colonial tutelage and those that remained in the forests, filling the natural niche. I do not know whether this version of history was selected strategically, or stems from a recognition that whatever their diverse pasts, many or all of the people who are now coming to identify themselves as masyarakat adat have a shared memory of the New Order as a key point of rupture.

Activists, Media and the National Popular

Debates about "the people" and the content of "the popular" are often conducted, as Watts (1999:92) reminds us, primarily between intellectuals. Activists and academics based in Jakarta and other major cities, people who are not themselves masyarakat adat, have played an important role in the emergence of the category and the resulting mobilization. Combining the imagery and resources of the international indigenous peoples' movement with the populist orientation of Indonesia's independence struggle, they undertake the cultural-political labor of translating innumerable, particular instances of violation into a common language, assembling them so they can be understood and potentially resolved on a national scale. Although translation inevitably entails power, as the memories, images and desires embedded in one idiom are subtly imposed upon the other (Asad I986), the activists do not see themselves as engaging in a process of transformation. Rather, they see themselves as affirming, and seeking to strengthen and preserve, what already exists: communities following customary ways that offer a healthy alternative to the kind of modernity offered by transnational capitalism and urban consumer culture in general, and the New Order regime in particular.

The activists who organized AMAN's inaugural congress must have had in mind the kinds of people that would be suitable as delegates, and hence some criteria for deciding who would, and who would not, qualify as masyarakat adat. The congress therefore had a somewhat tautological character: the people selected duly filled the slot, thus consolidating the category masyarakat adat as an embodied reality. Aware that they could be accused of "stage managing the whole event to fit their own 
agenda" (DTE-SI:I5), the organizers were careful to take a back seat at the Congress itself, giving the delegates as much time as possible to talk among themselves, discover commonalities, and constitute themselves as a united political force. Presumably, the activist organizers also learned something new while listening to the discussions, strengthening the grounds for acknowledgement.

The congress was surely designed, among other priorities, to have media appeal. There were photos, posters, and displays of handicrafts in the Jakarta hotel lobby. Delegates could be seen sitting in groups on the carpeted floor, smoking hand rolled cigarettes and chewing betel nut - behavior common enough in villages but unusual for the venue. Some of them elected to wear traditional dress, especially for the street marches and rallies. Down to Earth, the newsletter of the International Campaign for Ecological Justice in Indonesia, lamented in its coverage of the event that these choices had the effect of highlighting the exotic. "Journalists tended to focus on the plight of the Orang Rimba ... forest peoples from central Sumatra, who - barefoot and clad in loin cloths - fit the popular stereotype of indigenous communities rather than the political message of the event and the Indigenous Alliance, AMAN" (DTE-SI:II). Instead of having masyarakat adat fill the primitive slot that already exists in the popular imagination, Down to Earth envisages the construction of new niche which is recognizably "political”. But understandings of what counts as politics may also diverge. Down to Earth notes that the delegates spent too much time in their sessions with government ministers and politicians pleading for fair compensation in cases affecting their own communities instead of making "full use of the opportunity to demand political reforms, make policy recommendations or call for greater consultation". It notes that the indigenous delegates with their "lack of experience in confronting officialdom may have confirmed the Jakarta elite's prejudices that these were indeed "primitive peoples"' (DTE-SI:I2). Thus some of their activist supporters, in this case Down to Earth, consider that Indonesia's masyarakat adat need some improvement: they should become more politically savvy, perhaps more like indigenous people of the Americas who have honed their skills and their media images through decades of campaigning. They should focus on the big picture.

Media appeal is a complex matter for Indonesia's masyarakat adat. People looking out from Java's crowded cities and villages towards the outer islands are fully primed for difference, expecting to encounter scenes of culture and nature that diverge from their experiences at home. But what kind of culture will this be? Cultural diversity as colorful song and dance, especially in the glittering forms associated with court traditions, saturated Indonesian TV in the New Order period, since this was the form in which difference could most readily be accommodated (Pemberton 1994). In the absence of a racial distinction, masyarakat adat must also emphasise cultural 
difference, since the claim that they follow "customary" ways of life is central to their argument for sovereignty and resource rights. At the Congress, as noted earlier, it was the Orang Rimba who became the center of media attention, but there are risks in the identification of AMAN's platform with their plight. Outside activist circles, people who are seen as ill clad, ignorant, and forest dwelling are often despised and pitied not admired, and there is support for government intervention to assist and transform them. As far as I can tell, the noble savage has not been a trope with a mass following in Indonesia, although this could be changing.

In other contexts where indigenous people have made claims on the grounds of difference, they have been confronted by suspicious journalists, hostile publics - and scholars - anxious to expose a lack of authenticity, deconstruct images or disprove claims. According to Sharp (1996:9I) indigenous minorities "must assert an identity of fundamental cultural difference, of absolute primordial continuity with the precolonial past. If they did not do this, their claims for restoration of their dignity, for social justice, and for restitution for past dispossession would simply not be seen as legitimate. The unspoken rule is that those who make claims and demands on the basis of difference had better be really different" (emphasis in original). But in Indonesia, as my case study will illustrate, the burden of establishing difference does not seem to lie primarily on masyarakat adat themselves. Expectations about masyarakat adat, reflected through the prism of memory and desire, seem to operate powerfully in both activist and media circles to identify and highlight difference, reframing in an exotic light cultural practices which, under other conditions, might be regarded as unremarkable. ${ }^{13}$

\section{Limiting Recognition: Laws, Maps, and Exemplary Cases}

Having outlined the fields of power within and through which the demands of masyarakat adat have taken shape, I now turn to the processes through which claims for recognition are being limited or contained. My goal is to highlight the ways in which the competing agendas of masyarakat adat, their activist supporters, conservationists, and various branches of the state-apparatus are caught up and coordinated into a revised - but never solid - hegemonic formation. Laws, maps, and their contestation figure centrally in this scenario. So too does the phenomenon I am calling "the exemplary case:" a focus on unique and special places where difference takes on such spectacular proportions that all the contending parties can easily recognize and, indeed, affirm it, while leaving fundamental questions about the identity 
and rights of masyarakat adat unresolved. I use a case - the Orang Rimba we have already encountered - to illustrate.

\section{Laws and Maps}

A new forest law was passed in September 1999 by Habibie's interim reform cabinet amidst a storm of protest in which masyarakat adat figured prominently. The law contains many populist phrases about participation and forest access, adopting some of the language of activists and critics, but it stops far short of acknowledging the sovereignty of masyarakat adat or their right to manage their resources. The government is to decide whether or not masyarakat adat exist as a legally recognizable collectivity with a definite social organization, for which the law uses - tellingly - the Dutch term Rechsgemeenschap. The indicators include the presence of formal adat institution with recognized authority, a clearly defined territory, a body of customary laws which are still acknowledged and obeyed, and the dependence of people upon the collection of forest products to meet their daily subsistence needs. ${ }^{14}$ Thus to qualify for forest licenses, masyarakat adat must have both the institutional formality of a colonialera adat law regime, and be embedded in nature, an unlikely combination for the reasons I indicated earlier. Even those that do qualify are treated under this law as another category of licensed user of the national forest estate, their practices to be "guided", monitored and subject to regulation by the Forest Department. Moreover the law limits them to forest product collection, their projected "natural" niche, and sets steep fines for unlicensed uses including swidden farming and conversion to small holder tree crops - the principal livelihoods of the tens of millions of forest villagers AMAN would include in its constituency.

Activists mobilized to oppose the forest law, taking strident positions against a clear foe, while forming coalitions some of which crossed government/ activist lines. Members of Riau's provincial parliament joined a protest delegation to bring the "people's aspirations" to Jakarta (FKKM 15/09/99). The former ministers of forestry and of environment critiqued the law in a public statement, mentioning both environmental issues and the failure to acknowledge and protect the forest rights of masyarakat adat (Suryohadikusumo and Salim 15/06/99). Such high profile support indicates the increasing currency of the masyarakat adat concept as a vehicle for opposition politicians to express their populist concerns. AMAN warned of increased levels of conflict, national disintegration and civil disobedience (Io/09/99; 25/05/99). The Consortium for Agrarian Renewal (KPA) reiterated that there was no constitutional basis for the government's assertion of control over natural resources, and that nothing should take place within the sovereign domain of masyarakat adat without their informed consent (IO/o9/99). The Forum for Communication on Community Forestry (FKKM) opposed the law for its continued neglect and repression of the people 
described, interchangeably, as rakyat and masyarakat adat (Simon and Awang I2/05/99). It also expressed dismay at the process by which the new law was rammed through parliament, and at the content of the law, which bore little resemblance to the draft FFKM had prepared through protracted multi-stakeholder consultations with the Department of Forestry. A coalition of more than a hundred NGOs which adopted the name KUDETA (coalition for the democratization of natural resources, also coup d'etat) petitioned against the law on the populist grounds that it favors the elite at the expense of the environment and "the people" (rakyat) who had managed resources sustainably for generations (KUDETA 21/06/99). Green Robe of Kalimantan stressed the bond between masyarakat adat and nature: "The forest cannot be separated from the life of masyarakat adat. It is the center of their lives" (I5/09/99).

In its limited way, the Act accommodates popular demands for forest access through licensing schemes for customary (adat) forests and other programs (community forest, village forests), while advancing the governmental project of dividing and ordering population and resources according to bureaucratic imperatives (Vandergeest and Peluso 1995). Regardless of their label, these schemes have the same effect: to recognize peoples' presence in forested areas while conceding nothing on the issue of rights, and enmeshing them more securely in state regulatory regimes. Even when there is official acknowledgement of mistakes the Department of Forestry made in the (New Order) past (Anon I2/06/98), the governmental activity of reforming and improving the population continues under new rhetorics such as facilitation, participation, and the effort to increase villagers' understanding of forest matters (Anon 02/05/oo). Indeed, if the experience of community forestry in India and Nepal is indicative, such programs greatly intensify the level of micro-management of people and resources by government, while simultaneously invoking the effort of villagers to monitor and police themselves (Agrawal 200I; Shrestha 1999).

There are divergent interests at work in mapping. The World Bank has been involved in a long term land titling project intended to free up land for capitalist investment which would also have the effect - conveniently enough - of fulfilling its more recent commitment to recognize and protect indigenous land rights. But there is a disadvantage of detailed maps, from a government perspective. They diminish the power of officials to assign vast concessions to capitalist interests on the basis of vague land classifications, or to resolve conflicts expediently, according to their own priorities. Thus the continued illegibility of forest spaces, the lack of official data about the numbers and locations of people living within "government forest" and the inadequacy of official forest maps (Peluso I995:390-I) gives the forest department room for maneuver. ${ }^{15}$ Despite calls by activists and donors (Evers 1995) for a comprehensive 
inventory of forested areas and their users which identifies all the masyarakat adat and delimits their land, little progress is being made in this direction.

In a complex and perhaps ironic engagement with this field of force, it is masyarakat adat and their activist supporters who carry out the labor of documenting customary rules and regulations and preparing maps showing territorial boundaries and land use zones. Although the energy of the counter-mapping movement is impressive, not enough land is covered by these maps to seriously impinge on state prerogatives. They are usually drawn up under the stimulus of a resource conflict in which social and territorial boundaries are clearly drawn, and activist supporters are in attendance. These are precisely the conjunctures at which government officials need to effect a resolution of a particular, problematic "case". Responding to popular pressure, officials find that carefully delimited and documented claims made by unique and special people to unique and special places are, sometimes at least, eminently recognizable. The accommodation of special "cases" demonstrates the Department of Forestry's receptiveness to "new" ideas, without opening the flood gates to the tens of millions of people - call them masyarakat adat or simply rakyat - who could seriously challenge the claim that so much of Indonesia's land mass is state forest domain. Special cases of this kind also satisfy conservationists who are concerned about "ordinary villagers" invading protected areas, but ready to concede ground in cases which exemplify traditional, sustainable, resource management practices. Activists also need to be able to cite exemplary cases to support their more general claims.

Unplanned but strategic nonetheless, special cases are conjunctural sites that condense and simplify the problematic of nature and culture and coordinate between diverse agendas, but only so long as the groups singled out for special treatment are - or can be construed as - very different. It is difference which supplies the logic of the case focusing attention, delimiting categories, and reintegrating a hegemonic field frayed or rent by contestation.

Recognizing the Orang Rimba as an Exemplary Case

After the media drew attention to their sparsely clad bodies at AMAN's inaugural congress, the Orang Rimba were selected as one of five groups entitled to occupy places in the national assembly which had been designated - in response to popular pressure - for representatives of masyarakat adat. ${ }^{16}$ Then in January 2000 they won the Kehati award, a prize for biodiversity conservation given by a prominent NGO headed by Emil Salim, former minister of state for the environment. How did activists, the media, government officials and the public come to converge on the Rimba as an exemplary case?

According to a field study conducted by the NGO WARSI (Sandbukt and WARSI 1998), the Orang Rimba (people of the forest), comprise three groups. Those to the west 
have been severely affected by the Trans-Sumatran Highway which has brought official transmigrants, voluntary migrants, and large scale plantations to their lands. Mobile by tradition and also as a result of displacement, they live by some combination of rubber planting, share tapping, agricultural labor, swidden farming, forest-gathering, and begging at the roadside. A few have been allocated oil palm plots which they have leased out to Javanese settlers while they continue their own more diverse pursuits (1998:6-15). Though still recognizably Orang Rimba, these people do not form the coherent stable communities envisaged in arguments for adat land rights, nor does the idea of "sustainable forest management" begin to capture the fast-changing and highly pressured resource scenario with which they must contend. They are obviously needy, but they do not easily fit places of recognition constructed in terms of sovereign customary communities or conservation agendas. WARSI recommends that their rights to their remaining land be secured and, where available, additional land be purchased for them (1998:24-5). They are or should be on the way to becoming part of the "ordinary" village population.

The Orang Rimba of the Bukit Tiga Puluh area are similarly disorganized, many of them being outcasts or refugees from deforestation elsewhere (1998:22). They inhabit the buffer area of a national park also threatened with plantation development. They collect forest products from an extensive tract of hilly land that WARSI argues is unsuitable for conversion to plantation uses, but is of significant conservation value, notably as the habitat of elephants (1998:27). Natives in nature, part of a park, seems to be the place of recognition available here. The argument WARSI makes is more about Orang Rimba needs than rights, and it hangs on a fortuitous coincidence with the conservation agenda. Depending on definitions, the masyarakat adat claim might indeed be harder for these people to make, since they lack the coherent social and institutional relations that masyarakat adat need to qualify for forest rights under the new forest law, and they have not been fixed for generations in their current locale.

WARSI is especially concerned about the fate of the Bukit Dua Belas groups which maintain "an exceptionally integrated sociocultural system ... elaborated upon in a complex cosmology and supported by a political and legal structure that emphasizes the separateness and autonomy of the Orang Rimba tradition" (1998:I6). Part of their land falls within a biosphere reserve, but much of their swidden area and the forests they have modified and nurtured over generations fall outside the reserve and are under threat. The Orang Rimba's "low intensity silviculture ... makes them a very significant part of the forest ecosystem", as well as constituting "the basis for individual and collective claims to resources under traditional law" (1998:I6). In the effort to retain their traditions, some have withdrawn into the reserve, while others engage in limited ways with nearby transmigrant communities, selling them food produced in their 
swiddens. Two members of the group were killed as they tried to resist logging operations. Bukit Dua Belas is, according the WARSI, the Orang Rimba's cultural and demographic heartland. Thus "the dramatic marginalization of the Orang Rimba in other parts ... makes it all the more significant that they be allowed to maintain this central enclave where their identity remains intact" and in which they can "adapt to a changing world at their chosen pace" (1998:28). Once again the argument is framed in terms of needs rather than rights, and depends on a coincidence with a conservation agenda.

Media coverage of the NGO campaign to protect the forest of the Bukit Dua Belas has emphasized difference, sometimes against the odds. One reporter who went in search of Temenggung Tarib ${ }^{17}$ - the figure already encountered in Jakarta - described his abode "on a hilltop in the middle of dense primary forest where the air is cool, far from city noise". The report later mentions the very loud noise of bulldozers and chainsaws clearing for a nearby plantation, and the actual location of his house, only five hundred meters from a transmigration settlement (Thahar 30/8/99). "Orang Rimba: If the Forest is Finished, We Will Die", stated another headline (TP 7/II/99). The article explains sympathetically that the Orang Rimba have been forced into nomadism because their forests have been taken from them by greedy entrepreneurs or for national parks and reserves. When the reserves are raided by illegal loggers, the authorities do nothing to stop them, then blame Orang Rimba for the resulting destruction. The article supports WARSI's plan to extend the biosphere reserve to protect Orang Rimba and the watershed. "What happens to the Orang Rimba is an indicator of changes in the environment: if the Orang Rimba disappear, the conservation area that helps protect other areas will also be gone. The Orang Rimba really care for the environment, so they should be left in place. Let them change naturally, without being forced." It continues, "they just want to be free to cultivate and hunt in their traditional ways, living peacefully in the middle of the forest".

When Temenggung Tarib went to Jakarta to receive the Kehati award, news coverage described his discomfort, wearing long pants and a batik shirt, and his disorientation at flying, being above the sky instead of below it. It also described his problem with the hotel toilets - not because he did not know how to use them, the angle an unkind journalist might have highlighted, but because Orang Rimba have a taboo against soiling clean water - a lesson from which other Indonesians should learn (Julianto 3/2/oo). The report in the English paper the Jakarta Post was especially colorful, describing Tarib as a "Tarzan ... as innocent as fellow orang rimba (jungle people)" of the Kubu tribe who are nomads dependent on forest products like honey and resin. It adds, somewhat discordantly, that they also grow cassava, rubber and paddy (Anon 8/2/oo) - much like other villagers. 
Powerful images of Orang Rimba as unique and special people threatened by greed and destruction are ones to which government officials have been able to respond. According to the Forest Conservation Service of the Department of Forestry: "the Orang Rimba are very close to their environment and take care of it well ... The lifestyle of such people, who only wear loin cloths, is very modest but they remind us how important a modest lifestyle really is in the balance between people and nature". (TP 7/II/99). In recognition whereof, the Minister of Forests who visited the Province and met with WARSI and other activists in August 1999 agreed to cancel a logging permit covering a significant part of their traditional lands, giving them some security, at least for the moment (Anon 4/8/99).

The Kehati award highlighted Temenggung Tarib's knowledge of medicinal plants and the contribution he and his group were making to the protection of neighboring forest threatened by small holder expansion (Anon I/2/oo; Anon 29/oi/oo). Their technique, ironically enough, is to plant rubber trees of their own - a practice that they consider taboo, but which has enabled them to cordon off the forest from other villagers who would not by-pass Orang Rimba out of respect for their place as the legitimate occupants of the forest frontier (Anon 29/oI/oo; Thahar 30/8/99). The field of force at work here is complex indeed. Note that the case Kehati presents does not highlight the state-sponsored forest and plantation corporations, or the transmigration scheme, which have made the forest-frontier such a crowded place. It is villagers and illegal loggers who threaten the forest, yet the villagers are described sympathetically, as people who also acknowledge the Orang Rimba's special place - even when they are directly in competition for the expansion of rubber small holdings. Combine this with the journalistic magic and WARSI's conservation-oriented campaign noted above, and it becomes clear why so many can agree on the Orang Rimba and Temenggung Tarib. The place of recognition is quite limited, however, absorbing surprises and contradictions rather than embracing them as the grounds for new knowledge. Meanwhile, thousands of western Orang Rimba and other, less "special" villagers struggle on, their needs and rights unrecognized and even their presence ignored.

\section{Conclusions}

Attention to the dire needs of people who seem to exemplify difference does not preclude attending to the needs of others, perhaps through alternative approaches. Any recognition of the presence and the capacities of "customary" communities by government departments is significant, in view of counter arguments that customary practices lack intrinsic value or legal relevance, or are simply trumped by other agendas pursued "in the national interest". The hegemonic field dominated by New Order ideologies has been significantly disassembled, and residual and emergent 
forces are being recombined as NGOs, donors, the media, politicians, bureaucrats and those who consider themselves to be masyarakat adat reconfigure their identities, agendas, and mutual relations. Respect for cultural difference associated with nature conservation has become hegemonic, the kind of common sense on which many parties agree in principle, if not in detail.

The absence of clear boundaries to the category masyarakat adat provides the movement with important room for maneuver, but it also permits a rather formidable array of forces to narrow and limit the places of recognition that masyarakat adat may fill. When the international environmental lobby and donors connect biodiversity with indigenous people, they probably have in mind some famous exemplars, such as the Kayapo of the Amazon (Conklin and Graham 1995; Stearman 1994). Their images and expectations resonate readily with support for especially remote and exotic people, assumed to have large and unique reservoirs of biodiversity knowledge. They resonate less readily with the tens of millions of rather ordinary farmers who also have "customary" resource management practices and could well be considered masyarakat adat. Yet, so long as definitions remain vague and the compromise agenda focused on conservation can be invoked, support for the latter is not ruled out. Around the edges of consensus and compromise, struggles continue to be waged, often discretely, over the meaning of key terms as well as their applicability in particular contexts. Meanings are fixed, contingently, at the level of the "case".

Much less contentious than masyarakat adat and their demand for some kind of coequal sovereignty, the concept of natives attuned to nature is associated an attractive set of images, the approval of the international environmental lobby, and donor support. The same features that make the image attractive and serve to coordinate diverse agendas also impose limits. There are still many who question the motives of activists who would leave fellow humans in a state of nature, rather than help them out of it. The conservation alliance itself is precarious. Many of the complaints at AMAN's congress were against the appropriation of customary land for national parks. Exaggerated claims about the environmental wisdom of "indigenous people" are vulnerable to refutation by conservationists or by neighboring populations, if not now, when the challenge is limited to a few special "cases", then certainly in future as resource pressures increase. Such claims legitimate the restriction of rights to those who practice "traditional, sustainable" resource management. Government and conservation agencies can thus espouse the rhetoric, but find very few "cases" which meet the criteria in practice. Even when special status is granted, the benefits are uncertain. The "traditional" fisheries management system sasi - one of the first "cases" to receive broad recognition - has been subjected to an array of new government regulations and reporting requirements (Zerner 1994). The celebrated damar gardens of 
Krui are still not secure from appropriation by government and private sector interests despite their special legal status, and ninety Krui villages have been subjected to an "emptying" campaign (Safitri 1996).

Land and resource rights made contingent upon stewardship are a pale version of the rights other citizens effectively enjoy. So are rights linked to demonstrated "difference." But this paradox cannot be avoided if the demand of masyarakat adat is for recognition rather than - as in the case of the West Papuans - independence. Difference both enables claims to be made, and limits those claims by locating them within particular fields of power. This is the dilemma which, as Stuart Hall observes, besets the attempt to construct a politics "which works with and through difference, which is able to build those forms of solidarity and identification which make common struggle and resistance possible but without suppressing the real heterogeneity of interests and identities, and which can effectively draw the political boundary lines without ... fixing those boundaries for eternity" (1996b:444). The boundaries or limits are fixed, moreover, not only by processes of political mobilization but by the places of recognition that others provide. In the unsettling of those limits lie prospects for acknowledgement.

Agrawal, Arun

200I State Formation in Community Spaces?: Decentralization of Control over

Forests in the Kumaon Himalaya, India. Journal of Asian Studies 6o(I):9-40. AMAN, Aliansi Masyarakat Adat Nusantara Io/09/99 Masyarakat Adat Nusantara Monolak Rancangan Undang-Undang

Kehutanan (RUUK).fkkm@egroups.com. AMAN, Aliansi Masyarakat Adat Nusantara 25/05/99 Rancangan Undang-Undang Kehutanan Versi Pemerintah Tidak

Menghormati dan Melindungi Masyarakat Adat. fkkm@egroups.com. Anderson, Benedict

I99I Imagined Communities: Reflections on the Origin and Spread of Nationalism.

Revised and extended edition. London: Verso. Anon

I/2/oo Jaringan Kehidupan Ada Pada Hubungan Ketergantungan. Kompas. Anon

oi/05/oo Pemberdayaan Hutan Dapat Kurangi Utang Negara. Suara Pembaruan. Anon 02/05/oo Mengelola Hutan Bersama Masyarakat. Suara Merdeka. Anon 04/03/oo Timber Firms Halt Work Due To Conflict With Locals. Jakarta Post. 
Anon

4/8/99 Perjuangan WARSI Berhasil Inhutani Diminta Cabut IPK. Jambi Express.

Anon

8/2/oo Temenggung Tarib Wages Peaceful Resistance against Loggers. Jakarta Post.

Anon

09/03/oo Conflicts Between Locals and Timber Companies to Grow. Jakarta Post.

Anon

Io/og/oo Warga Sangir Tersinggung. Kompas.

Anon

I2/06/98 Kembalikan Hutan Kepada Rakyat. Kompas.

Anon

25/03/oo Logging Companies Ready to Share Revenues with Locals. Jakarta Post.

Anon

29/oi/oo "Kehati Award" untuk Temenggung Tarib. Kompas.

Asad, Talal

I986 The Concept of Cultural Translation in British Social Anthropology. In Writing

Culture: The Poetics and Politics of Ethnography. J. Clifford and G. Marcus, eds. pp.

I4I-I64. Berkeley: University of California Press.

Beteille, Andre

I998 The Idea of Indigenous People. Current Antrhopology 39(2):I87-I92.

Brosius, J. Peter

1999a Anthropological Engagements with Environmentalism. Current Anthropology 40(3):277-309.

Brosius, J. Peter

I999b Green Dots, Pink Hearts: Displacing Politics from the Malaysian Rain Forest.

American Anthropologist IOI(I):36-57.

Burns, Peter

I989 The Myth of Adat. Journal of Legal Pluralism 28:I-I27.

Conklin, Beth, and Laura Graham

I995 The Shifting Middle Ground: Amazonian Indians and Eco-Politics. American

Anthropologist 97(4):695-710.

Cooper, Frederick

I994 Conflict and Connection : Rethinking Colonial African History. American

Historical Review 99(5):I5I6-I545.

Cronon, William

I996 The Trouble with Wilderness; or, Getting Back to the Wrong Nature. In

Uncommon Ground. W. Cronon, ed. pp. 69-90. New York: W. W. Norton and

Company. 
Dove, Michael

1985 The Agroecological Mythology of the Javanese and the Political Economy of Indonesia. Indonesia (39):I-35.

Dursin, Richel

24/o2/oo Illegal Loggers Now Bolder, Activists Say. IPS.

Erni, Christian

1996 Indigenous Peoples in South and Southeast Asia: Between 2oth Century

Capitalism and Oriental Despotism. In Vines that Won't Bind: Indigenous Peoples

in Asia. C. Erni, ed. pp. 15-36: Copenhagen: International Working Group for

Indigenous Affairs (IWGIA).

Evers, Pieter J.

1995 Preliminary Policy and Legal Questions about Recognizing Traditional Land

Rights in Indonesia. Ekonesia 3:I-23.

Fabian, Johannes

1999 Remembering the Other: Knowledge and Recognition in the Exploration of Central Africa. Critical Inquiry 26:49-69.

Fauzi, Noer

Io/09/99 Hapus Konsepsi Hak Menguasai Negara: Kritik Terhadap RUU Kehutanan versi Departemen Kehutanan. fkkm@egroups.com.

Fisher, Larry, Ilya Moeliono, and Stefan Wodicka

nd Cattle, Cockatoos, Chameleons, and Ninja Turtles: Seeking Sustainability in Forest Management and Conservation in Nusa Tenggara, Indonesia. .

FKKM

15/o9/99 DPRD Tk.I Riau Dukung Penolakan RUU Kehutanan. fkkm@egroups.com. Foucault, Michel

199I Governmentality. In The Foucault Effect: Studies in Governmentality. G.

Burchell, C. Gordon, and P. Miller, eds. Chicago: University of Chicago Press.

Gray, Andrew

1995 The Indigenous Movement in Asia. In Indigenous Peoples of Asia. R. H. Barnes,

A. Gray, and B. Kingsbury, eds. pp. 35-58. Ann Arbor: The Association for Asian

Studies.

Green Robe

I5/09/99 Tolak RUU dari Kalimantan Barat. fkkm@egroups.com.

Hale, Charles R.

1999 Does Multiculturalism Menace? Governance, Cultural Rights and the Eclipse of

"Official Mestizaje" in Central America. In Paper prepared for the session

"Indigenismo/Mestizaje: New Views on Key Concepts in Latin American Cultural

History" of the annual meetings of the American Anthropological Association, 1999. 


\section{Hall, Stuart}

I985 Signification, Representation, Ideology: Althusser and the Post-Structuralist Debates. Critical Studies in Mass Communication 2:9I-II4.

Hall, Stuart

1996a Gramsci's Relevance for the Study of Race and Ethnicity. In Stuart Hall: Critical Dialogues in Cultural Studies. D. Morley and K.-H. Chen, eds. pp. 4II-44O. London: Routledge. Hall, Stuart

1996b New Ethnicities. In Stuart Hall: Critical Dialogues in Cultural Studies. D.

Morley and K.-H. Chen, eds. pp. 44I-449. London: Routledge. Hall, Stuart

1996c What is this 'Black' in Black Popular Culture. In Stuart Hall: Critical Dialogues

in Cultural Studies. D. Morley and K.-H. Chen, eds. pp. 465-475. London: Routledge. Hooe, Todd R.

1999 Enduring Changing Currents: Adat Law and Social Hierarchy in the Kei Islands, Eastern Indonesia. American Anthropological Association, Chicago, 1999. Julianto, Irwan 3/2/oo Temenggung Tarib Digusur "Rajo Godong". Kompas. Kingsbury, Benedict 1998 "Indigenous Peoples" in International Law: A Constructivist Approach to the Asian Controversy. The American Journal of International Law 92(3):4I4-457. Kisbandono, Heru I8/02/93 Kepala BPN akan Matikan Hukum Adat. Forum Keadilan. KUDETA, Koalisi untuk Demokratisasi Sumberdaya Alam 2I/o6/99 Petisi Menolak RUU Kehutanan dan RUU Migas. fkkm@egroups.com (posted on Io/o9/99).

Kusumatmadja, Sarwono

1993 The Human Dimensions of Sustainable Development. In Proceedings, Seminar on the Human Dimensions of Environmentally Sound Development. Arimbi, ed. pp. I2-I5. Jakarta: WALHI and Friends of the Earth. Langenberg, Michael Van 1990 The New Order State: Language, Hegemony and Ideology. In State and Civil

Society in Indonesia. A. Budiman, ed. pp. I2I-I49. Monash Papers on Southeast Asia No.22. Clayton, Victoria: Monash University.

Li, Tania Murray I996 Images of Community: Discourse and Strategy in Property Relations.

Development and Change 27(3):50I-527.

Li, Tania Murray 
I997 Producing Agrarian Transformation at the Indonesian Periphery. In Economic Analysis Beyond the Local System. R. E. Blanton, P. N. Peregrine, D. Winslow, and T. D. Hall, eds. pp. I25-I46. Lanham: University Press of America.

Li, Tania Murray

I999 Compromising Power: Development, Culture and Rule in Indonesia. Cultural Anthropology I4(3):I-28.

Li, Tania Murray

2000 Articulating Indigenous Identity in Indonesia: Resource Politics and the Tribal

Slot. Comparative Studies in Society and History 42(I):I49-I79.

Li, Tania Murray

200I Relational Histories and the Production of Difference on Sulawesi's Upland

Frontier. Journal of Asian Studies 6o(I):4I-66.

Li, Tania Murray

Forthcoming Engaging Simplifications: Community Based Resource Management,

Local Processes and State Agendas in Upland Southeast Asia. In Representing

Communities: Histories and Politics of Community-Based Natural Resource

Management. P. Brosius, A. Tsing, and C. Zerner, eds.

Lynch, Owen J., and Kirk Talbott

I995 Balancing Acts: Community-Based Forest Management and National Law in

Asia and the Pacific. Washington: World Resources Institute.

Mallon, Florencia E.

I994 The Promise and Dilemma of Subaltern Studies: Perspectives from Latin

American History. American Historical Review 99(5):I49I-I5I5.

Moniaga, Sandra

I993 Toward Community-Based Forestry and Recognition of Adat Property Rights in the Outer Islands of Indonesia. In Legal Frameworks for Forest Management in

Asia : Case Studies of Community/State Relations. J. Fox, ed. pp. I3I-I50. Honolulu:

East-West Center Program on Environment.

Peluso, Nancy Lee

1995 Whose Woods Are These? Counter-Mapping Forest Territories in Kalimantan, Indonesia. Antipode 27(4):383-406.

Pemberton, John

1994 On the Subject of Java. Ithaca: Cornell University Press.

Pieterse, Jan Nederveen

I998 My Paradigm or Yours? Alternative Development, Post-Development, Reflexive

Development. Development and Change 29(2):343-373.

Prakash, Gyan 
1994 Subaltern Studies as Postcolonial Criticism. American Historical Review 99(5): I475-I490.

Rahail, Johannes Paulus

I996 Adat Society in the Islands of Kei (Evav), South-East Maluku. In Vines that

Won't Bind: Indigenous Peoples of Asia. C. Erni, ed. pp. I87-I94: Copenhagen:

International Working Group on Indigenous Affairs (IWGIA).

Richardson, Michael

oI/o2/oo Indonesia Faces Forest Dilemma. International Herald Tribune.

Roseberry, William

I996 Hegemony, Power, and Languages of Contention. In The Politics of Difference:

Ethnic Premises in a World of Power. E. N. Wilmsen and P. McAllister, eds. pp. 7I-84.

Chicago: University of Chicago Press.

Ruwiastuti, Maria R.

I998 Menuju Pluralsime Hukum Agraria: Analisa dan Kritik terhadap Marginalisasi

Posisi Hukum-hukum dan Hak-hak Adat Penduduk Asli atas Tanah dan Sumber-

sumber Agraria oleh UUPA 1960. In Usulan Revisi Undang-Undang Pokok Agraria:

Menuju Penegakan Hak-Hak Rakyat atas Sumber-Sumber Agraria. KRHN and

KPA, eds. Jakarta and Bandung: Kornsorsium Reformasi Hukum Negara and

Konsorsium Pembaruan Agraria.

Safitri, Myrna

I996 Saresehan Tentang Akses Masyarakat Lokal Pada Sumberdaya Hutan Dalam

Penerapan Peraturan Perundang-undang. Ekonesia 4:I36-I4I.

Sandbukt, Oyvind, and WARSI

I998 Orang Rimba: Needs Assessment for Resource Security and Development: The

Wold Bank and the Government of Indonesia.

Schild, Veronica

I997 New Subjects of Rights? Women's Movements and the Construction of

Citizenship in the "New Democracies". In Cultures of Politics, Politics of Cultures:

Revisioning Latin American Social Movements. S. E. Alvarez, E. Dagnino, and A.

Escobar, eds. pp. 93-II7. Boulder: Westview Press.

Scott, David

I995 Colonial Governmentality. Social Text 43:I9I-220.

Scott, David

I999 Refashioning Futures: Criticism after Postcoloniality. Princeton: Princeton

University Press.

Scott, James C.

I998 Seeing Like a State: How Certain Schemes to Improve the Human Condition

Have Failed. New Haven, CT: Yale University Press. 
Sharp, John

1996 Ethnogenesis and Ethnic Mobilization: A Comparative Perspective on a South

African Dilemma. In The Politics of Difference: Ethnic Premises in a World of

Power. E. N. Wilmsen and P. McAllister, eds. pp. 85-I03. Chicago: University of

Chicago Press.

Shrestha, Neeru

1999 Forest Control, Development and State Formation in Nepal. Doctoral

Dissertation in Interdisciplinary Studies. Dalhousie University.

Simon, Hasanu, and San Afri Awang

I2/05/99 From Critique towards an Alternative Natural Resource Management Law

(RUU PSDH).fkkm@egroups.com.

Social Affairs, Department of

1994/95 Isolated Community Development: Data and Information. Jakarta: Directorate

for Development of Isolated Communities.

State Ministry for Environment and United Nations Development Program, KLH/

UNDP

I997 Agenda 2I-Indonesia: A National Strategy for Sustainable Development.

Jakarta: KLH/UNDP.

Stearman, Allyn MacLean

1994 Revisiting the Myth of the Ecologically Noble Savage in Amazonia: Implications

for Indigenous Land Rights. Culture and Agriculture 49:2-6.

Stolcke, Verena

I995 Talking Culture: New Boundaries, New Rhetorics of Exclusion in Europe.

Cultural Anthropology 36(I):I-24.

Suryohadikusumo, Djamaludin, and Emil Salim

15/06/99 Perlu Penundaan Pembicaraan RUU Kehutanan. fkkm@egroups.com.

Taylor, Charles

1994 The Politics of Recognition. In Multiculturalism: Examining the Politics of

Recognition. A. Gutman, ed. pp. 25-73. Princeton: Princeton University Press.

Thahar, Nasrul

30/8/99 Kami Orang Kubu. Kompas.

TP, Sumedi

7/II/99 Orang Rimba: Jika Hutan Habis, Matilah Kita. Suara Pembaruan.

Tsing, Anna Lowenhaupt

1993 In the Realm of the Diamond Queen: Marginality in an Out-of-the-Way Place.

Princeton: Princeton University Press.

Tsing, Anna Lowenhaupt 
1999 Becoming a Tribal Elder, and other Green Development Fantasies. In

Transforming the Indonesian Uplands: Marginality, Power and Production. T. M. Li, ed. pp. I59-202. Amsterdam: Harwood Academic Publishers.

Vandergeest, Peter, and Nancy Lee Peluso

I995 Territorialization and State Power in Thailand. Theory and Society 24:385-426. Watts, Michael John

I999 Collective Wish Images: Geographical Imaginaries and the Crisis of National

Development. In Human Geography Today. D. Massey, J. Allen, and P. Sarre, eds.

pp. 85-107. Cambridge: Polity Press.

Wilmsen, Edwin N.

I996 Introduction: Premises of Power in Ethnic Politics. In The Politics of Difference:

Ethnic Premises in a World of Power. E. N. Wilmsen and P. McAllister, eds. pp. I-24.

Chicago: University of Chicago Press.

Zerner, Charles

I994 Through a Green Lens: the Construction of Customary Environmental Law and

Community in Indonesia's Maluku Islands. Law \& Society Review 28(5):IO79-II22.

I The term native (asli) excludes the few Dutch who stayed on after independence and the Chinese, still marked racially as well as culturally even after generations of residence and intermarriage. Gray (1995) and Kingsbury (1998) acknowledge the descriptive incoherence of the term indigenous in much of Asia, where it refers less to a fixed group of people than to a sentiment which emerges in the course of struggles over territories, resources and cultural respect - rather like the "imagined community" of the nation (Anderson 199I). For reasons that have more to do with national laws than population composition, the International Working Group on Indigenous Affairs (IWGIA) registers only I\% of Indonesia's population as indigenous, compared to I6\% in the Philippines, and 60\% in Nepal (Erni 1996:20).

${ }^{2}$ Contrast the scenario in Europe described by Stolcke (1995), in which cultural fundamentalism is a polite reconstruction of enduring racism.

3 There have been bloody battles between Dayaks and immigrant Madurese in Kalimantan, and between Muslims and Christians in Maluku and Sulawesi, although there are reports that the latter were instigated by the military.

4 On the issue of migration from interiors to coasts see $\mathrm{Li}$ (200I). 
5 Wilmsen (I996:ix, 5, 8) gives priority to class. See Watts (I999:88, IOI) on the dangers of racializing territory.

${ }^{6}$ See Scott (I999:I25, I54). Contrast Wilmsen's (1996:7) account of Australian aboriginal elites conceptualizing and constructing an identity space and inviting rural aborigines to fill it, only to have it co-opted, manipulated and contained by the European dominated national government. The sequence is familiar enough, but the causal links inadequately explored.

7 On subaltern complexity see Mallon (I994:I496, I502); Prakash (I994:I480).

${ }^{8}$ On governmentality as improvement, see David Scott (1995). Here I diverge from Brosius who sees governmentality as the activity of regulation and surveillance by states, and advocacy or "politics" as the domain of moral causes espoused by NGOs and social movements, "nonstate, nomadic ... grassroots groups ... outside the space of institutional sovereignty" (I999b:50). Brosius argues that such groups should not be too closely studied lest the hidden transcripts of their rhizomatic practices be revealed (I999a:288). But many rhizomes cross-cut government/ nongovernment lines. See, for example, Hale's (I999) account of the convergence between Maya demands for cultural rights, exerting pressure from below, and new strategies of governance which adopt the language of multiculturalism to exclude activists who go "too far". Pieterse (1998) argues that mainstream development agencies have absorbed critiques to such an extent that the search for a development "alternative" is now incoherent, while the IMF conducts business as usual. Schild (1997) describes how Chile's new democratic government took on the rhetoric, practices, and personnel of the once-radical women's movement, deploying them to governmental ends. These processes of disassembly and reconstruction cannot be understood if the "N" in NGO is conceded without scrutiny. 9 NGOs and villagers understand endless negotiation to be a government ploy. See Fisher et al (nd) on the limits to what can be achieved by increasing communication between stake-holders, and the compromised position of NGOs caught between the roles of advocates and mediators in conflicts over conservation.

Io See more generally Lynch and Talbot (1995), and my discussion of Lynch's work in Li (Forthcoming). 
${ }^{\text {II }}$ Dutch scholars disagreed on the nature of adat rights, their spatial extent, and their implications for sovereignty. The subtext was racializing and Orientalist, based on an assumption of unalterable difference between east and west. Van Vollenhoven, the key figure, added to these premises a liberal respect for human rights, a concern for peasant welfare and a respect for cultural diversity. He acknowledged native sovereignty, but expected natives to consent to commercial uses of their traditional lands so long as they were consulted and given a token customary payment called - tellingly - recognitie (Burns 1989:14). Opponents argued that the logical conclusion of Van Vollenhoven's approach would be the recognition of adat law areas as mini-republics, leaving the colonial power with an "inchoate claim to govern" (Burns 1989:IO2). Such recognition would expose "the contradictions at the heart of colonialism" (Burns 1989:I04) - a contradiction which still besets both the successor "national" regime and contemporary adat activism. The problem has been more severe in Indonesia than elsewhere in Asia because the Dutch recognized that all natives had adat, making no sharp distinction between peasant masses and tribes. In contrast, the British in India made and marked the boundary by means of a "schedule" (Beteille 1998), while the U.S. in the Philippines quickly consolidated older distinctions with its mapping and listing of the "non-Christian tribes".

${ }^{12}$ Hooe (1999) discusses the use of adat law to justify and maintain elite dominance in the Kei islands of Eastern Indonesia, and the increasing comfort of government officials with rule by and through these "traditional" elites. The presentation on Kei customary law at the IWGIA did not discuss these embedded inequalities, focusing instead on harmony, mutual assistance and consensus (Rahail 1996).

${ }^{13}$ See Tsing (1999), (Li 2000).

${ }_{14}$ See clause 67 and its explanation.

${ }^{15}$ Here and in Li (1999; 200I) I argue, contra Scott (1998), that illegibility has an ongoing role in modern systems of rule.

${ }^{16}$ The other four were from Irian, Kalimantan, Maluku, and Sulawesi, although the latter were apparently insulted by being placed in what they perceived as a primitive slot (Anon Io/og/oo). 
${ }^{17}$ Temenggung is a Malay title used by the Dutch in the context of indirect rule. 